\title{
Do Obstetric Factors Have an Effect on Success of Medical Treatment of Anal Fissure Seen in Women?
}

\section{Kadınlarda Görülen Anal Fissürün Medikal Tedavi Başarısında Obstetrik Faktörlerin Etkisi Var Mıdır?}

\author{
-Hacı Bolat', @Bülent Çakmak² \\ 'Niğde Ömer Halisdemir University School of Medicine Department of General Surgery, Niğde, Turkey \\ ${ }^{2}$ Niğde Ömer Halisdemir University School of Medicine Department of Obstetrics and Gynecology, Niğde, Turkey
}

\begin{abstract}
Objective: The aim of this study is to examine the effect of obstetric factors on the medical treatment success of anal fissure in women.

Material and Method: A total of 324 women, who were diagnosed with anal fissure, who applied to the General Surgery outpatient clinic between 2015 and 2020, were included in the study. The patients were divided into two groups; group I (medical treatment was successful) and group II (medical treatment failed - surgery performed). Both groups were compared in terms of age, body mass index (BMI), number of births, delivery type, birth weight, breastfeeding rate, constipation, diarrhea, smoking and anal fissure symptoms.

Results: Medical treatment was applied to all of the 324 patients we included in our study, and it was observed that $45.7 \%$ of them had successful medical treatment and $54.3 \%$ had undergone surgical treatment (lateral internal sphincterotomy) because of unsuccessful medical treatment. It was found that age, BMI, number of births, number of vaginal births, breastfeeding rate, constipation rates were higher in those who failed medical treatment $(p<0.05)$. The number of cesarean sections, birth weight, diarrhea and smoking were found to be similar between the two groups ( $p>0.05$ ). While gas incontinence was observed in $44.1 \%$ of those who underwent surgical treatment, this rate was found to be $1.4 \%$ in those who benefited from medical treatment.

Conclusion: In our study, it was found that while maternal age, number of births, vaginal delivery and breastfeeding rates had a negative effect on the success of anal fissure medical treatment, cesarean delivery and baby birth weight were not effective.
\end{abstract}

Keywords: Anal fissure, pregnancy, delivery, obstetrics, medical therapy

\section{Öz}

Amaç: Bu çalışmanın amacı, kadınlarda görülen anal fissürün medikal tedavi başarısında obstetrik faktörlerin etkisinin incelenmesidir.

Gereç ve Yöntem: Çalışmaya2015-2020 yılları arasında Genel Cerrahi polilliniğine anal bölge rahatsızlığı nedeni ile başvurup anal fissür tanısı almış 324 kadın dahil edildi. Hastalar iki gruba ayırıldı; grup I (medikal tedavi başarılı) ve grup II (medikal tedavi başarısız - cerrahi yapılan). Her iki grup yaş, vücut kitle indeksi (VKI), doğum sayısı, doğum şekli, bebek doğum ağılığı, emzirme oranı, kabızlık, ishal, sigara içme ve anal fissür semptomları açısından karşılaştırıldı.

Bulgular: Çalışmamıza aldığımız 324 hastanın tümüne medikal tedavi uygulanmış olup bunlardan \%45,7'sinde medikal tedavi başarılıyken, \%54,3'ünde ise medikal tedavi başarısız olduğundan dolayı cerrahi tedavi (lateral internal sfinkterotomi) uygulandığı gözlendi. Medikal tedavi başarısız olanlarda yaş, VKi, doğum sayısı, vajinal doğum sayısı, emzirme oranı, kabızlık oranlarının daha fazla olduğu tespit edildi $(p<0,05)$. Sezaryen sayısı, bebek doğum ağırlığı, ishal ve sigara kullanımının iki grup arasında benzer olduğu bulundu ( $p>0,05$ ). Cerrahi tedavi uygulananlarda \%44,1 gaz inkontinansı görülürken medikal tedaviden yarar görenlerde bu oran \%1,4 saptandı.

Sonuç: Çalışmamızda gebelik sürecinde oluşan anal fissür medikal tedavi başarısında obstetrik etkenlerden maternal yaş, doğum sayısı, vajinal doğum ve emzirmenin olumsuz yönde etki ettiği görülürken sezaryenle doğum ve bebek doğum kilosunun etkili olmadığı saptandı.

Anahtar Kelimeler: Anal fissür, gebelik, doğum, obstetrik, medikal tedavi

Corresponding (Illetişim): Bülent Çakmak, Niğde Ömer Halisdemir University School of Medicine Department of Obstetrics and Gynecology, Niğde, Turkey

E-mail (E-posta): drbulentcakmak@hotmail.com

Received (Geliş Tarihi): 26.03.2021 Accepted (Kabul Tarihi): 31.05 .2021 


\section{INTRODUCTION}

Anal fissure is one of the frequently recurring, quite disturbing anorectal diseases that are quite common in society. While it often leads to severe pain and itching, it may rarely bleed. The diagnosis is made by anamnesis and anal canal examination. ${ }^{[1]}$ If the patient's complaints continue for more than 1-1.5 months, the disease is considered chronic. ${ }^{[2]}$ Fissures are occurred at the same rate in both gender groups. ${ }^{[3]}$ Most women complain of anal disorders during pregnancy and birth-process. While the most common disease among these lesions is haemorrhoids, the second disease is anal fissure. ${ }^{[4]}$ The main cause of these lesions has been shown as injury to the anal mucosa due to constipation. In addition to the most common risk factor being constipation, it has been emphasized that the birth weight of the child, the time elapsed during the termination of pregnancy and perianal diseases are also important..$^{[5,6]}$

Acute anal fissure patients recover at a rate of $40-80 \%$ with the treatment of mainly constipation-preventing diet with dense fiber, abundant oral fluid intake, sitz baths in the anal area and drugs containing calcium channel blockers, diltiazem, nifepidine or glyceryl trinitrate ${ }^{[7,8]}$ However, if the symptoms of the patients persist for more than six months, the medical recovery rate decreases to $8 \% \cdot{ }^{[7,9]}$ Especially in women, the disease is diagnosed late because they tell their complaints of anal fissure late or do not tell their complaints at all because of the sociocultural and environmental effects, and this reduces the medical treatment success rate. ${ }^{[10]} \mathrm{An}$ incurable anal fissure can cause severe discomfort, especially during pregnancy and post-partum, causing severe pain that may disturb the pregnancy and the delivery process. ${ }^{[1]]}$

This study aims to examine the effect of obstetric factors in the success of medical treatment of anal fissure seen in women.

\section{MATERIAL AND METHOD}

324 patients who presented to the General Surgery polyclinic and were diagnosed with anal fissure, dating between 2015 and 2020, were included in the study. The study was conducted in accordance with the Declaration of Helsinki, after the approval of the Niğde Ömer Halisdemir University Medical Faculty Non-interventional Ethic Committee dated 27/08/2020 and numbered 2020/41.

All female patients included in the study were examined by the same physician in the general surgery clinic. Physical examination of the patients was performed by paying attention to the presence of ulcers, skin tags and pseudo polyps in the anal region in the prone position. Rectal examination was not performed avoid pain. Anal fissure was diagnosed in patients who have at least one of the complaints of pain, bleeding, itching or swelling in the anal area and has a rupture in anal area on physical examination. Inclusion criteria in the study was determined as having a diagnosis of anal fissure with a pregnancy history between the ages of 18 and 60 and being or not being recovered after receiving a medical treatment and receiving surgical treatment (lateral internal sphincterotomy), exclusion criteria were determined as having a history of chronic gastrointestinal disease (ulcerative colitis, Crohn's, malignancy), anal canal surgery without anal fissure, and having a psychiatric disease.

Patients with anal fissure were divided into two groups as those who benefited from medical treatment (Group-l) and those who received surgical treatment (due to medical treatment failure) (group-II). The treatment was considered successful in patients who did not have any complaints due to anal fissures within at least six months after medical treatment. The information of all participants included in the study was recorded by asking their age, body mass index (BMI), number of births, mode of delivery, infant's weight, breastfeeding time, complaints when diagnosed (bleeding, pain, swelling, itching), constipation and diarrhoea complaints, and whether they had post-surgical faecal incontinence. This information was compared among two groups.

Statistical analysis was carried out with SPSS (SPSS Statistics version 22.0, SPSS inc.) statistical software. While t-test was used for parametric values in statistical comparisons, Pearson chisquare and Fisher's Exact test were used for categorical variables. Categorical variables were shown as number and percentage $(\mathrm{n}$; $\%$ ), while numeric variables as mean \pm standard deviation (mean $\pm S D) . P<0.05$ was accepted statistically significant.

\section{RESULTS}

Medical treatment for anal fissure was administered to all 324 patients included in the study and the success rate was $45.7 \%$ (148/324), while the rate of not benefiting from medical treatment and applying surgical treatment was recorded as $54.3 \%(176 / 324)$. When the two groups were compared in terms of demographic characteristics, age and body mass index (BMI) were determined to be lower in Group-l according to group-II $(p<0.05)$. When the comparison was made in terms of obstetrics, the total number of births, the number of vaginal deliveries and the breastfeeding rate were determined to be lower in Group-I $(p<0.05)$, while there was no statistically significant difference between the two groups in terms of the number of caesarean deliveries and baby birth weight ( $p>0.05)$. While constipation was more common in group-II, there was no statistically significant difference found between the two groups in terms of diarrhoea and smoking (Table 1).

While pre-treatment bleeding and pain symptom presence was of lower rate in Group-l, both groups had similar characteristics in terms of the presence of swelling and itching symptoms. While fluctuation complication rate after medical treatment (Group-I) was $1.4 \%$, this rate was determined to be $44.1 \%$ after surgical treatment (group-II) $(\mathrm{p}<0.001)$.

It was found that 324 patients with anal fissure (AF), which we included in our study, recovered at a rate of $45.7 \%$ with medical treatment, however $54.3 \%$ did not respond to medical treatment and were administered surgical treatment. In medical treatment failure, age, BMI, parity, vaginal parity, breastfeeding rate, constipation had negative effects. 
However, it was observed that the C-section parity, birth weight of the baby, diarrhoea and smoking did not affect. Gas incontinence was observed in $44.1 \%$ of those who were administered surgical treatment, while it was seen in $1.4 \%$ of those who received medical treatment.

\begin{tabular}{lccc}
\hline \multicolumn{3}{lc}{ Table 1: Comparison of demographic, obstetric features and symptoms } \\
\hline & $\begin{array}{c}\text { Group I } \\
\text { (n=148) }\end{array}$ & $\begin{array}{c}\text { Group II } \\
\text { (n=176) }\end{array}$ & p-value \\
\hline Demographic characteristics & & & \\
Age & $35.2 \pm 9.8$ & $40.1 \pm 9.2$ & $<0.001$ \\
BMI & $20.4 \pm 2.5$ & $21.1 \pm 3.5$ & 0.044 \\
Smoking & $48.3 \%$ & $51.7 \%$ & 0.846 \\
Constipation & $41.6 \%$ & $\% 58.4$ & $<0.001$ \\
Diarrhoea & $72.7 \%$ & $27.3 \%$ & 0.120 \\
Obstetric features & & & \\
Number of Births & $2.0 \pm 1.2$ & $2.3 \pm 0.9$ & 0.008 \\
Vaginal Delivery & $1.5 \pm 1.3$ & $2.0 \pm 1.1$ & 0.004 \\
C/S & $0.4 \pm 0.7$ & $0.3 \pm 0.5$ & 0.246 \\
Infant Weight & $3472 \pm 366$ & $3475 \pm 450$ & 0.952 \\
VD Infant Weight & $3464 \pm 377$ & $3413 \pm 443$ & 0.393 \\
Lactation & $41.4 \%$ & $58.6 \%$ & $<0.001$ \\
Symptoms & & & \\
Bleeding & $29.4 \%$ & $70.6 \%$ & $<0.001$ \\
Itching & $42.1 \%$ & $52.2 \%$ & 0.182 \\
Pain & $42.1 \%$ & $57.9 \%$ & 0.004 \\
Swelling & $34.8 \%$ & $65.2 \%$ & 0.114 \\
Complication & & & \\
Faecal Incontinence & $1.4 \%$ & $44.3 \%$ & $<0.001$ \\
\hline BMI: Body Mass Index, C/S: C-section, VD: Vaginal Delivery & & \\
\hline & & &
\end{tabular}

\section{DISCUSSION}

Vaginal delivery causes deep and superficial injuries to the anal mucosa and muscles depending on the duration and number of births, ending up in anal fissure. ${ }^{[12},{ }^{13]}$ Trauma in the anal canal has been detected in approximately $50 \%$ of women who performed vaginal delivery. ${ }^{[14]}$ In women who gave birth by $\mathrm{C}$-section, anal fissure is quite low, rating around $1.2-15.2 \%$. ${ }^{[11]}$ In our study, it was found that the vaginal births and its parity affect to anal fissure treatment; a direct relationship was found between the high number of vaginal deliveries and the patients who were not benefiting from medical treatment and going to surgical treatment.

Although etiological factors in anal fissure formation are controversial, it has been shown that they are associated with increased pressure in the anal canal. ${ }^{[15]}$ Internal sphincter pressure increases due to obesity, constipation, sitting for a long time, and prolonged straining. It has been asserted that this increase in internal sphincter pressure may cause anal fissure by causing ischemia in the posterior anal canal mucosa by compressing the branches of the inferior rectal artery. ${ }^{[16},{ }^{17]}$ In our study the medical treatment success rate of anal fissure in breastfeeding mothers with high BMI was found to be low. It suggests that this is related to the fact that the situation may become chronic due to the increase in the pressure in the anal area caused by the mothers who sit for a long time every two hours and breastfeed their child and repeat this frequently. Because, studies have reported that $33-44 \%$ of women experience discomfort due to anal region lesions in the first months after birth. ${ }^{[18]}$ For this reason, frequent breastfeeding by sitting may make anal region lesions chronic.

Age is important in medical treatment success, and a higher success rate has been reported, especially in young patients with anal fissure compared to older patients. ${ }^{[19]}$ In our study, medical therapy was found to be unsuccessful in elderly patients, in accordance with the literature. The reason for the traumatization of the anal canal as a result of hard defecation, constipation, and long-lasting straining, paves the way for anal fissure formation. ${ }^{[20]}$ In women, it has been reported that traumatization of the anal area mucosa due to constipation, diarrhoea, and anorectal sexual intercourse is effective in the formation of anal fissure. ${ }^{[2]]}$ If constipation which causes anal fissure is not diagnosed early and treated, it makes the situation chronic and reduces the response to medical

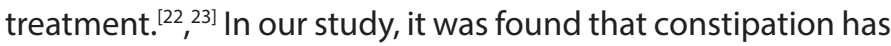
a statistically significant effect on failure of medical treatment of anal fissure.

The long duration of anal pain, itching and bleeding symptoms seen in anal fissure indicate that the disease becomes chronic and this reduces the response to medical treatment. ${ }^{[24]}$ Similarly, in our study, it was found that the presence of clinical symptoms contributed to the failure of the medical treatment.

The limitations of our study are that it is a retrospective study and not evaluating the presence of pelvic organ prolapse and urinary incontinence, while the strength of our study is that it is the first study to mention the medical treatment failures of anal fissure during pregnancy.

\section{CONCLUSION}

In our study, among obstetric reasons, number of pregnancies and vaginal deliveries and breastfeeding were negative factors in the success of the medical treatment of anal fissure during pregnancy. Also age and excess body weight are among other important reasons. Anal area lesions can be reduced by taking precautions such as diet, sitting bath, and receiving early medical treatment before pregnancy and delivery in order to reduce this negative condition that women experience, which is mostly ignored.

\section{ETHICAL DECLARATIONS}

Ethics Committee Approval: Approval of the Niğde Ömer Halisdemir University Medical Faculty Non-interventional Ethic Committee dated 27/08/2020 and numbered 2020/41.

Informed Consent: Because the study was designed retrospectively, no written informed consent form was obtained from patients. 
Referee Evaluation Process: Externally peer-reviewed.

Conflict of Interest Statement: The author(s) declared no potential conflicts of interest with respect to the research, authorship, and/or publication of this article.

Financial Disclosure: The authors declared that this study has received no financial support.

Author Contributions: All of the authors declare that they have all participated in the design, execution, and analysis of the paper, and that they have approved the final version.

\section{REFERENCES}

1. Adamová Z, Slováček R, Bár T, Sankot J VP. Anal fissure. Cas Lek Ces. 2015;154:11-3.

2. Nelson R. A Systematic Review of Medical Therapy for Anal Fissure. Diseases of the Colon and Rectum. Dis Colon Rectum; 2004;47:422-31.

3. Hananel N, Gordon PH. Re-examination of clinical manifestations and response to therapy of fissure-in-ano. Dis Colon Rectum. 1997;40(2):22933.

4. Ferdinande K, Dorreman Y, Roelens K, Ceelen W, De Looze D. Anorectal symptoms during pregnancy and postpartum: a prospective cohort study. Color Dis. 2018;20(12):1109-16.

5. Freymond JM, Chautems R, Santa V Della, Wolter L. Proctological emergencies in pregnant women. Rev Med Suisse. 2018;14(614):1394-6.

6. Poskus $T$, Buzinskiene $D$, Drasutiene $G$, et al. Haemorrhoids and anal fissures during pregnancy and after childbirth: A prospective cohort study. BJOG An Int J Obstet Gynaecol. 2014;121(13):1666-71.

7. Emile $\mathrm{SH}$, Elgendy $\mathrm{H}$, Elfeki $\mathrm{H}$, et al. Does the duration of symptoms of anal fissure impact its response to conservative treatment? A prospective cohort study. Int J Surg. 2017;44:64-70.

8. Altomare DF, Binda GA, Canuti S, Landolfi V, Trompetto M, Villani RD. The management of patients with primary chronic anal fissure: A position paper. Techniques in Coloproctology. Tech Coloproctol; 2011;15:135-41.

9. Poh A. Innovations in chronic anal fissure treatment: A systematic review. World J Gastrointest Surg. 2010;2(7):231.

10. Meyer I, Richter HE. Impact of fecal incontinence and its treatment on quality of life in women.Women's Health. Future Medicine Ltd.; 2015;11:225-38.

11. Abramowitz L, Batallan A. Epidemiology of anal lesions (fissure and thrombosed external hemorroid) during pregnancy and post-partum. Gynecologie Obstetrique et Fertilite. Elsevier Masson SAS; 2003;31:546-9.

12. Faridi A, Willis S, Schelzig P, Siggelkow W, Schumpelick V, Rath W. Anal sphincter injury during vaginal delivery - An argument for cesarean section on request? In: Journal of Perinatal Medicine. J Perinat Med; 2002;379-87.

13. Poskus $T$, Buzinskienè $D$, Drasutiene $G$, et al. Haemorrhoids and anal fissures during pregnancy and after childbirth: a prospective cohort study. BJOG An Int J Obstet Gynaecol. 2014;121(13):1666-71.

14. Murad-Regadas SM, Regadas FSP, Filho FSPR, et al. Pubovisceral muscle and anal sphincter defects in women with fecal or urinary incontinence after vaginal delivery. Tech Coloproctol. 2021;23(2):117-28.

15. Beaty JS, Shashidharan M. Anal Fissure. Clinics in Colon and Rectal Surgery. Thieme Medical Publishers, Inc. 2016;29:30-7.

16. Klosterhalfen B, Vogel P, Rixen H, Mittermayer C. Topography of the inferior rectal artery. Dis Colon Rectum. 1989;32(1):43-52.

17. Abramowitz L, Batallan A. Epidemiology of anal lesions (fissure and thrombosed external hemorroid) during pregnancy and post-partum. Gynecologie Obstetrique et Fertilite. Elsevier Masson SAS; 2003;31:546-9.

18. Abramowitz L, Sobhani I, Benifla JL, et al. Anal fissure and thrombosed external hemorrhoids before and after delivery. Dis Colon Rectum. 2002;45(5):650-5.

19. Jamshidi R. Anorectal Complaints: Hemorrhoids, Fissures, Abscesses, Fistulae. Clin Colon Rectal Surg. 2018; 31(2):117-20.
20. Jahnny B, Ashurst JV. Anal Fissures. In: Stat Pearls. Treasure Island (FL): Stat Pearls Publishing. 2020.

21. Beaty JS, Shashidharan M. Anal Fissure. Clinics in Colon and Rectal Surgery. Thieme Medical Publishers, Inc.; 2016;29:30-7.

22. Constipation in children and young people: diagnosis and management. Constipation in children and young people: diagnosis and management. National Institute for Health and Care Excellence (UK); 2017

23. Felt-Bersma RJF, Bartelsman JF. Haemorrhoids, rectal prolapse, anal fissure, peri-anal fistulae and sexually transmitted diseases. Best Pract Res Clin Gastroenterol.2009; 23(4):575-92.

24. Nelson RL. Anal fissure (chronic). BMJ clinical evidence. BMJ Publishing Group; 2014;2014. 